\title{
TŁUMACZENIA
}

Warszawskie Studia Pastoralne UKSW

Rok XI 2016 Nr 3 (32)

Johannes Schelhas*

(Trewir)

\section{PAPIEŻA FRANCISZKA ROZUMIENIE PRYMATU}

Epokowe przełomy zwiastują nadejście nowych czasów. Równocześnie potrzebni są ludzie, którzy zmiany z tym związane $\mathrm{z}$ determinacją kształtują i im towarzyszą. Takim człowiekiem jest papież Franciszek. Treści, które zawierają się w tych stwierdzeniach, prowokując do dalszej refleksji, chciałbym tu rozwinąć, uzupełniając je na początek o nieco ociężałą wypowiedź doktrynalną: „Władza jurysdykcyjna zna stopnie papiestwa i episkopatu. O ile biskupi są w następcami apostołów i każdy z nich ma udział w powszechnej władzy biskupiej, to papież jest następcą określonego Apostoła, świętego Piotra (...). Papieżowi przysługuje pełna władza jurysdykcyjna. Jest on biskupem biskupów. Jego władza święceń nie wychodzi jednak poza władzę biskupią. Biskup otrzymuje władzę jurysdykcji wraz z zastrzeżoną mu równocześnie władzą święceń” ${ }^{1}$. W taki oto rzeczowy sposób Michael Schmaus (1897-1993), katolicki dogmatyk i doradca soborowy monachijskiego arcybiskupa kardynała Juliusa Döpfnera, opisuje urząd biskupi. Schmaus wypowiada swój pogląd na kilka lat przed tym, jak ostatni Sobór przedłożył nowe rozumienie urzędu biskupiego oraz służby Piotrowej, co w kilkanaście lat później znalazło też swój wyraz w zaplanowanej przez Sobór reformie Kodeksu Prawa Kanonicznego.

* Johannes Schelhas (1961) doktoryzował się w 2000 Frankfurt/St. Georgen, w 2011 habilitacja w Bonn; jest profesorem dogmatyki i historii dogmatów na Wydziale Teologicznym Uniwersytetu w Trewirze (Trier). Oryginał: Das Primatsverständnis des Papstes Franziskus, Catholica 69 (2015) nr 3, s. 170-181.

1 M. Schmaus, Vom Wesen des Christentums, Ettal ${ }^{3}$ 1954, s. 308. 
Według pewnego teologa między papieżem a biskupami jest więcej rzeczy wspólnych niż dzielących. Jakie są to rzeczy? Które należą do prerogatyw biskupów, a które do papieża? Od wieczora 13 marca 2013 (sic!) rozmowa tego teologa z papieżem Franciszkiem na temat sposobu sprawowania przez niego nowego urzędu zyskała aktualność, jakiej trudno byłoby wcześniej się spodziewać.

\section{Biskup Rzymu}

Podczas swojego pierwszego wystąpienia w loggi Bazyliki Świętego Piotra Franciszek w zaskakujący sposób mówił o sobie nie jako o papieżu, ale jako o biskupie Rzymu. We właściwym sobie wyrazistym języku, niekiedy drastycznym, stwierdził, że Kościół ciągle ma z bojaźnią nasłuchiwać, a odpowiadając latem 2014 na pytanie dziennikarzowi powiedział: „Pierwszą służbą Franciszka jest być biskupem Rzymu. Wszystkie tytuły papieża: pasterz powszechny, namiestnik Chrystusa i tak dalej - nosi on właśnie dlatego, ponieważ jest biskupem Rzymu. Jest to decyzja w związku z prymatem, konsekwencja prymatu Piotra. Jeśli papież zechciałby rano być biskupem Tivoli, oczywiście wówczas, przepędzono by mnie"2. Tivoli jest nieobsadzonym biskupstwem w pobliżu Rzymu. Biskup Rzymu powinien być radosny, cierpliwy i niezłomny ${ }^{3}$, aby urbi et orbi, miastu Rzymowi i kręgowi ziemi, przepowiadać Ewangelię. Inne tytuły i predykaty są podporządkowane urzędowi biskupa Rzymu, przy czym należy podkreślić ten szczególny: servus servorum Dei. Piastujący ten urząd podejmuje wysiłki, aby ten tytuł właściwie odpowiadał duchowi wspólnoty Jezusa.

\section{Biskup Rzymu a ekumenia}

Istota misji papieża, gdy idzie o jego biskupią służbę w Rzymie, sprowadza się przede wszystkim do ekumenii. Ową ekumeniczną

2 Jest to odpowiedź papieża Franciszka na pytanie dziennikarza rzymskiego dziennika „Il Messaggerio” (z czerwca 2014): „Dlaczego Wasza Świątobliwość od początku podkreślał funkcję biskupa Rzymu?”, OR(D) 44 (2014) nr 32/33 z 8 VIII 2014, s. 11 .

3 Por. Papież Franciszek, Adhortacji apostolska Evangelii gaudium, nr 110. 
orientację następcy Piotra należy wyjaśnić w dwóch węzłowych punktach związanych ze stosunkami międzywyznaniowymi.

Koncentracja urzędu papieskiego rozumianego jako biskupa Rzymu umożliwia stymulację eklezjalnego dialogu „w prawdzie i w miłości” z Kościołami prawosławnymi w „duchowej radości”. Spotkanie „biskupów Kościoła Rzymu i Konstantynopola, założonych przez Piotra i Andrzeja - Apostołów-braci” - jak to się zwykło oficjalnie określać - nadaje ruchowi ekumenicznemu wymowny wyraz. Wspólna deklaracja papieża Franciszka i ekumenicznego patriarchy Bartłomieja I z Konstantynopola podpisana w Jeruzalem 25 maja 2014 podkreśla, że „właściwy dialog” pomyślany jest jako „pogłębianie własnego rozumienia całej prawdy, którą Chrystus ofiarował swojemu Kościołowi”. Jest to „prawda, w którą wsłuchani poddajemy ciągłej refleksji postępując za natchnieniami Ducha Świętego”. Biskup Kościoła Rzymu i biskup Kościoła Konstantynopola deklarują wspólne poszukiwanie Jezusa Chrystusa, którego ekumenicznym celem jest dialog dwóch sakramentalnie ukonstytuowanych Kościołów, nie rezygnując przy tym z osiągnięcia widzialnej jedności. Widzialna jedność jest darem Ducha Świętego; teologicznie określa się ją jako „jedność w uprawnionej różnorodności”. Obydwaj biskupi wyrażają przekonanie, że „przez wymianę darów i pod kierownictwem Ducha Świętego" istnieje wspólna droga, która te dwa złączone w wierze, a więc w tym, co konieczne ${ }^{5}$, Kościoły doprowadzi do „pełnej wspólnoty".

Kiedy pielgrzym z Rzymu, kierując się do pielgrzymów z Konstantynopola (Jeruzalem, maj 2014) odniósł się do współczesnej ${ }^{6}$ wykładni perykopy o pustym grobie Jezusa, uważni obserwatorzy odnotowali, że Papież - wbrew oczekiwaniom wielu - nie interpretował słów

${ }^{4}$ Papież Franciszek, Apostolische Reise Seiner Heiligkeit (...) ins Heilige Land: Predigten, Ansprachen und Grussworte. 24.-26. Mai 2014. Hg. v. Sekretariat der Deutschen Bischofskonferenz, Bonn 2014 (VAp5 197). Odwołania do obecności na stronach umieszczone są w nawiasach.

${ }^{5}$ Por. DE 4; KDK 92.

${ }^{6}$ Por. KO 12, gdzie sformułowany jest dezyderat obowiązującej wykładni Pisma Świętego. 
o skale - owych kluczowych słów, będących do dzisiaj podstawą obrazu Piotra i jego pozycji w Kościele katolickim (por. Mt 16,18n). Według papieża Franciszka Piotr jest świadkiem Zmartwychwstania - „serca chrześcijańskiej nowiny”. Na tej prawdzie wspiera się wiara. Nie tylko obydwaj biskupi, ale „każdy ochrzczony w Chrystusie” jest człowiekiem „Zmartwychwstania, a nie śmierci”. „Troski naszych Kościołów i całego świata” (muszą ukierunkować każdego biskupa „na światło poranka wielkanocnego". Ekumenia z Kościołami prawosławnymi wymaga zdaniem papieża Franciszka - zapału, cierpliwości i wiary. Realistycznie, ale i z nadzieją przeciwną rezygnacji i niewierze ocenia: „Jesteśmy świadomi, że należy pokonać wiele jeszcze dalszych (sic) przeszkód, by osiągnąć pełną wspólnotę, która swój wyraz znajdzie w jednej Uczcie eucharystycznej, której niecierpliwie wyglądamy: jednak nie możemy bać się sporów i powodować paraliż w naszym podążania do przodu". Biskup Rzymu w ekumenii wspólnego świadectwa, przynoszącej owoce na fundamencie modlitwy o jedność wierzących (por. J 17,21), widzi możliwość osiągnięcia pełnej wspólnoty eklezjalnej między Kościołem Rzymu a Kościołami prawosławnymi.

Tymczasem gdy idzie o wspólnoty chrześcijańskie zrodzone z Reformacji i późniejszych podziałów Kościoła, papież Franciszek koncentruje się na obowiązujących przekonaniach, z uwzględnieniem hierarchii prawd ${ }^{7}$, by „szybko osiągnąć wspólną formę przepowiadania służby i świadectwa” (EG 246). Z rzadką otwartością kieruje się papież Franciszek do chrześcijan ewangelikalnych i zielonoświątkowców. Podczas prywatnej wizyty w gminie zielonoświątkowej w Caserta (lipiec 2014) konstatuje niezależnie od podziałów: „Duch Święty sprawia 'różnorodność' w Kościele (...). Ale oprócz tego Duch Święty sprawia też jedność, tak że Kościól jest jeden w wielości. Dzięki Duchowi Świętemu jest on (...) 'pojednaną wielością. Sprawia On obydwie. Sprawia wielość darów duchowych oraz harmonię tych darów. (...) Duch Święty nie sprawia jednostajności”8. Jego działa-

\footnotetext{
7 Por. DE 11.

8 Przemówienie papieża Franciszka z okazji spotkania z pastorem Giovanni Traettino we Wspólnocie Zielonoświątkowców w Caserta 28.07.2014,
} 
nia dają biskupom przebudzenie i umożliwiają wspieranie różnych charyzmatów wśród wiernych.

Powodzenie ewangelizacji świata może dokonać się jedynie dzięki współdziałaniu możliwie największej grupy chrześcijan (nie tylko rzymskich katolików) podążających w dziele Jezusa z powodu Jego zbawczej miłości. Papież Franciszek zwraca się do każdego, kto głosi Ewangelię, chcąc obudzić większe zaangażowanie: „Nie można wytrwać w ewangelizacji pełnej zapału, jeśli nie jest się przekonanym na podstawie doświadczenia, że to nie to samo: poznać Jezusa lub nie znać Go; że to nie jest to samo: podążać z Nim lub kroczyć po omacku; że to nie jest to samo: raczej móc Go słuchać, niż ignorować Jego słowo" (EG, 266). Osobisty wkład wierzących z powodu spotkania z Jezusem Chrystusem odmienia oblicze ziemi. W ocenie wierzących papież Franciszek uważa się za ekumenicznego inspiratora.

Obecne zaangażowanie ekumeniczne chrześcijan w bezkrwawym męczeństwie codzienności obejmuje też zwrócenie się do wszystkich ludzi dobrej woli, obejmuje wkład na rzecz pokoju, sprawiedliwości, walki z głodem, biedą i społecznym uciskiem w świecie jak również „efektywny dialog z judaizmem, islamem i innymi tradycjami religijnymi”.

W podsumowaniu można powiedzieć, że papież Franciszek drogę Kościoła ku jedności, choć bardzo zróżnicowaną i obliczoną na dłuższy czas, widzi w klarownych konturach. Krzesze bodźce, aby lud Boży - w świecie ciemności, w półmroku czy w przesłoniętym świetle Boga - „w Kościele” i „wokół Kościoła”9 tętnił i mógł otwarcie kroczyć śladami Chrystusa (por. 1 P 2, 21). Koncentracja na urzędzie biskupa Rzymu czyni ekumeniczną przestrzeń bardzo rozległą, obejmującą dziś wiele innych Kościołów i wspólnot chrześcijańskich. Ta przestrzeń kształtowana jest w rozmaitych dialogach, które w odpowiedzialności wobec wspólnego poznawania prawdy, poprzez ewangelizację urzeczywistniają widzialną jedność wierzących.

<http:w2.vatican.va/kontent/Francesco/de/speeches/2014/july/documents/papa-francesco_20140728caserta-pastore-traettino.html, 2f.> (dostęp: 09.04.2015).

9 G. Greshake, Der dreieine Gott. Eine trinitarische Theologie, Freiburg i. Br. 2007, s. 406 . 


\section{Biskup Rzymu a Kościół rzymsko-katolicki w świecie}

Społeczność Jezusa ma do dyspozycji wiele kryteriów w doborze zadań apostolskich. Kryteria te winien uwzględniać przełożony, przydzielając konkretne zadania swoim podwładnym. Św. Ignacy Loyola daje w związku z tym wytycznę: „Przydzielając komuś misję, należy mieć na uwadze podstawową regułę: wola pełnienia największej służby Bożej oraz największego dobra powszechnego; wydaje się, że w tak ogromnej winnicy Chrystusa, naszego Pana, należy wybrać na podobnych warunkach (...) część z tego, co jest najbardziej potrzebne"10. Kiedy papież Franciszek został wybrany na biskupa Rzymu, w Kościele dały o sobie znać - ujmując rzecz skrótowo niepokojące zjawiska: egoizm Kościoła, zanikająca akceptacja jego nauczania wśród ochrzczonych, rzymski centralizm - wszystko to wiązało się z niewydolnością skuteczności Kurii Rzymskiej i braku należytego rozpędu gdy idzie o ewangelizację o zasięgu światowym, stanowiąc główną przeszkodę w rozwoju sił duchowych Kościoła w wielu częściach świata. W duchu kolegialności i synodalności, w postawie pokory i modlitwy papież Franciszek podjął się zadania uzdrowienia sytuacji i przezwyciężenia braków. Nawiasem mówiąc podobnie czyni on $\mathrm{z}$ regułą swojego zakonu.

Już jako arcybiskupa Buenos Aires Jorge Mario Bergoglio SJ poruszała troska o żywotność Kościoła we wszystkich jego członkach. W dokumencie końcowym V Zgromadzenia Ogólnego Episkopatu Ameryki Łacińskiej i Karaibów, pod którym widnieje podpis kardynała Bergoglio ${ }^{11}$, stwierdza się niezgodność między wiarą a życiem w praktyce duszpasterskiej. Dokument z Aparecida domaga się wzmocnienia w Kościele czterech elementów. Są nimi: (a) doświadczenie religijne, (b) życie wspólnotowe, (c) formacja biblijno-teologiczna

\footnotetext{
10 Ignatius von Loyola, Gründungstexte der Gesellschaft Jesu, tłum. P. Knauer, Würzburg 1998 (Deutsche Werkausgabe 2), s. 762.

11 Por. W. Kasper, Papst Franziskus - Revolution der Zärtlichkeit und der Liebe. Theologische Wurzeln und pastorale Perspektiven, Stuttgart 2015, s. 95. Polskie tłum.: Papież Franciszek. Rewolucja czułości i miłości. Korzenie teologiczne i perspektywy duszpasterskie, tłum. Michał Tadeusz Szwemin, Warszawa 2015 (uwaga tłum.).
} 
oraz (d) zaangażowanie misyjne całej gminy ${ }^{12}$. Co w roku 2007 okazało się słuszne dla konkretnego regionu w celu przebudzenia tam Kościoła, okazało się też konieczne dla Kościoła na wszystkich kontynentach. Kościół we wszystkich swych członkach potrzebuje dziś przebudzenia, powstania i pójścia śladami Jezusa. „On pozwala nam podnieść głowę i zacząć od nowa, z taką czułością, która nas nigdy nie zawiedzie i zawsze może przywrócić nam radość" - napisał papież Franciszek w Evangelii Gaudium, dopowiadając z wiarą: „Nic nie może być większe od Jego życia, które pozwala nam iść naprzód” (EG 3). Aby tak się stało, świadectwo wiary musi „wszystkim wiernym pomóc w 'osobistym spotkaniu z Jezusem Chrystusem’, w głębszym i bardziej intensywnym doświadczeniu religijnym, w przepowiadaniu kerygmatycznym oraz w osobistym świadectwie tych, którzy przepowiadają Ewangelię. Wszystko to ma doprowadzić do osobistego nawrócenia i głębokiej przemiany życia" ${ }^{13}$. Ów element doświadczenia wskazany przez dokument z Aparecida jest do zaakceptowania przez ewangelików i zielonoświątkowców. Wyraźną analogię do powyższej wypowiedzi znajdujemy w Evangelii gaudium (nr 3). Papież Franciszek poszukuje dróg Chrystusa w powołaniu poszczególnych osób, pozwala poszukiwać innych, nowych dróg w urzeczywistnianiu kolegialności i razem z ludem Bożym podąża nimi, stawiając Ewangelię na świeczniku i czyniąc ją solą ziemi. W tym wszystkim biskup Rzymu urzeczywistnia dziś prymat Piotra. W zrozumieniu jego postępowania konieczna jest znajomość dokumentu biskupów latynoamerykańskich; wniknięcie we Franciszkowe rozumienie prymatu po prostu domaga się lektury dokumentu z Aparecida ${ }^{14}$.

Nie zagłębiając się w specyficznie dogmatyczne i duszpasterskie zagadnienia związane z małżeństwem i rodziną, które były przedmiotem

\footnotetext{
12 Por. Aparecida 2007, Schlussdokument der 5. Generalversammlung des Episkopats von Lateinamerika und der Karbik, 13-31. Mai 2007, Hg. v. Sekretariat der Deutschen Bischofskonferenz, Bonn 2007 (SWK 41), Nr. 226.

13 Tamże, nr 226.

14 Por. N. Arntz, Pastorale Umkehr. Das Programm des Franziskus-Pontifikats, Vortrag am 9. Oktober 2013: <http:wirsindkirche.de/files/2102_GR_Arntz_Pastorale_Umkehr.pdf, 9> (dostęp: 09.04.2015).
} 
zainteresowania Nadzwyczajnego Synodu Biskupów 2014, chciałbym odnieść się do idei kolegialności i synodalności realizowanych z biskupem Rzymu i pod biskupem Rzymu. Stosunek synodu biskupów czy biskupów do papieża wyraził papież Franciszek zwięzłą formułą: cum Petro et sub Petro ${ }^{15}$. Kolegialność i synodalność biskupów, zgodnie z tym, co wcześniej powiedziano, ma swe źródło we wzajemnych oddziaływaniach, jakie wynikają z wielkich wyzwań o charakterze regionalnym czy kontynentalnym, z konieczności angażując dla swych rozwiązań cały Kościół. Co jest do zrobienia, w nieubłagalny sposób domaga się szybkiej realizacji. W taki oto sposób papież Franciszek uzasadnia swój ciągły niepokój o Kościół i gorliwy zapał, jaki towarzyszy jego troskom. Nie znosi zwłoki, którą ma za dzieło szatana. Kolegialność i synodalność biskupów jest równocześnie życzeniem Soboru Watykańskiego II: Franciszek jako biskup Rzymu domaga się „kolegialnego charakteru i natury episkopatu”"16, aby zgodnie z tą zasadą kolegialnie i synodalnie nieść posługę Kościoła ludowi Bożemu. Sformułowanie Soboru waloryzuje owo cum Petro. Jak biskup Rzymu z (cum) całym ludem Bożym w Kościele rzymsko-katolickim i poza nim działa, tak też czyni każdy biskup w swoim lokalnym Kościele. Co we własnej mierze realizują biskupi i Kościoły lokalne, urzeczywistnia biskup Rzymu wobec całego Kościoła w świecie. Dokument z Aparecida przynosi konstatację: „Lud Boży zorganizowany jest jako wspólnota Kościołów lokalnych. Dzięki tym Wspólnotom różne kultury pozostają we wzajemnej wymianie. W ten sposób biskupi i Kościoły lokalne zaznaczają swą troskę o wszystkie Kościoły”"17. Oznacza to, że duchowa wymiana, jaka się dokonuje między Kościołami lokalnymi oraz wymiana między kulturami możliwa jest tylko z czynnym udziałem papieża ${ }^{18}$.

\footnotetext{
15 Przemówienie papieża Franciszka na zakończenie III Nadzwyczajnego Zgromadzenia Synodu Biskupów (18.X.2014); Aparecida 2007 (przyp. 12), nr 181 (z odwołaniem do Jana Pawła II); zob. też KK, 13; 23).

16 Konstytucja dogmatyczna o Kościele Lumen gentium, 22.

17 Aparecida 2007 (przyp. 12), nr 182.

18 Por. tamże, nr 181.
} 
Biskup Rzymu ocenia Synod Biskupów 2014 jako wspólną drogę przebytą przez pasterzy z całego świata: „Mogę spokojnie powiedzieć, że w duchu kolegialności i synodalności przeżyliśmy prawdziwie doświadczenie 'synodu': solidarnej drogi, 'wspólnego pielgrzymowania"'19. Następnie papież Franciszek omawia specificum synodalnej i kolegialnej drogi Kościoła, traktując zresztą te określenia jako w gruncie rzeczy synonimy. „A ponieważ była to 'droga', to podobnie jak na każdej drodze były momenty szybkiego marszu, jakby pragnienie pokonania czasu i jak najszybszego osiągnięcia celu. Były też chwile zmęczenia, jakby chciało się powiedzieć: dość. Były też inne chwile: entuzjazmu i zapału. Były chwile głębokiego pocieszenia, kiedy słuchaliśmy świadectw prawdziwych pasterzy, którzy roztropnie biorą sobie do serca radości i łzy swoich wiernych. (por. J 10 oraz kan. 375, kan. 386, kan. 387). (...) A ponieważ była to droga ludzi wraz z chwilami pocieszenia były też chwile przygnębienia, napięć i pokus". Doświadczanie - w wierze - kolegialności w Kościele zapewnił ostatni Synod całemu ludowi Bożemu. Co artykułują ojcowie synodalni odnośnie małżeństwa i rodziny, mutatis mutandis uchodzi za głos samego Synodu: dyskusje nie są celem samym w sobie, lecz w nich manifestuje się głos Ducha Bożego w Kościołach lokalnych. Dlatego wspólnota synodalna potrzebuje wytrwałości i cierpliwości. „Podczas tej drogi, która niekiedy jest ścieżką na wyżynach, z trudami i upadkami, zawsze obecny jest i towarzyszy nam Bóg" ${ }^{20}$. Wydarzenie synodalne - ów proces będący wspólną drogę biskupów złączonych w kolegium biskupów z biskupem Rzymu, papież Franciszek uzasadnia także autorytetem Kodeksu Prawa Kanonicznego z 1983. Kanony kodeksowe można rozumieć w odniesieniu do sub Petro, jeśli zauważy się, że implikują one pierwszeństwo biskupa wobec ludu Bożego oraz sytuują wyżej pozycję biskupa Rzymu nad innych biskupów (kan. $375 \S 2$ ). Jeśli więc papież Franciszek, wskazując na Jezusa Chrystusa

\footnotetext{
19 Przemówienie papieża Franciszka (przyp. 15). Następujący cytat tamże.

20 „Kościół Chrystusa jest domem, który dla wszystkich jest otwarty”. Przesłanie III Nadzwyczajnego Zgromadzenia Synodu Biskupów do ludu Bożego (18 października 2014), przyp. 15.
} 
jako dobrego pasterza, odwołuje się do słuchania i do biskupów, uzasadniając to trzema kanonami Kodeksu Prawa Kanonicznego, to nadaje tym kanonom interpretację teologiczną, która wychodzi poza ich sens wyrazowy. Ta łagodna i intuicyjna interpretacja, by tak rzec w duchu chrystologiczno-pneumatologicznym, znajduje swą podstawę w dokumencie z Aparecida ${ }^{21}$. Następnie można ją oprzeć na stwierdzeniu Dekretu o pasterskich zadaniach biskupów w Kościele Christus Dominus, gdzie jest mowa, że biskupi mają być sługami swych wiernych i ich znać ${ }^{22}$, tak i papież ma zachować podobną postawę względem biskupów. Papież musi zatem być słuchaczem słowa, jaki dochodzi z Kościołów lokalnych. Posłuszeństwo biskupa Rzymu wobec innych biskupów jest istotnym elementem jego władzy prymacjalnej. To posłuszeństwo stanowi kryterium dogmatyczno-teologicznego rozumienia prymatu.

Z doświadczeniem synodu, drogi czy wspólnego pielgrzymowania łączy papież Franciszek ciągłą reformę Kościoła, od której nie może uchylić się ani jego Głowa czy członkowie kolegium biskupów, ani jakikolwiek inny członek Kościoła, najbardziej zaś jednak sama Kuria rzymska. Dogmatyczno-teologiczną intencję reformy Kurii wyprowadza obecny biskup Rzymu z charakteru Kościoła, który jest narzędziem $^{23}$ : „Ten cel, jaki trzeba osiągnąć, zawsze wymaga większej harmonii w pracy różnych dykasterii i biur, aby umożliwić większą skuteczność współpracy przy całkowitej przejrzystości, która buduje prawdziwą synodalność i kolegialność. Reforma nie jest celem samym w sobie, lecz środkiem dla zapewnienia bardziej wyrazistego świadectwa chrześcijańskiego; dla skuteczniejszego wspierania dzieła ewan-

\footnotetext{
21 Por. Aparecida 2007 (przyp. 12), nr 181.

22 DB nr 16: „W wykonywaniu swych zadań ojca i pasterza niech biskupi będą pośród swoich jako ci, co usługują, niech będą dobrymi pasterzami, znającymi swe owce i przez nie znanymi; prawdziwymi ojcami, wyróżniającymi się duchem miłości i troski względem wszystkich, tak że ich władzy pochodzącej od Boga wszyscy się z wdzięcznością poddają. Całą rodzinę swej trzody niech tak skupiają i urabiają, by wszyscy, świadomi swych obowiązków, żyli i działali we wspólnocie miłości”. ${ }^{23}$ Por. wypowiedzi na temat tych narzędzi Kościoła: (a) zgodnie ze słowem i sensem: KK, nr 1 (,instrumentum”); (b) zgodnie z sensem: DM, nr 1, 2-3, 5.
} 
gelizacji; dla bardziej owocnego wspierania ducha ekumenicznego; dla krzesania bardziej konstruktywnego dialogu ze wszystkimi"24. Częste uciekanie się papieża Franciszka do stosowania (gramatycznego) stopnia wyższego, pozwala mu wyrazić (jak choćby dosłownie na Konsystorzu 2015) prawdę, że Kościół na tej drodze za każdym razem lepiej wypełni swą kompleksową misję, zapewniając jej większą wiarygodność w świecie.

Podsumowując można powiedzieć: pierwszeństwo biskupa Rzymu zapewnia sprawującemu urząd Piotrowy nie tylko kolegialny i synodalny kontakt $\mathrm{z}$ innym biskupami oraz z całym ludem Bożym. Kolegialność i synodalność, będące w służbie bardziej skutecznej ewangelizacji, są esencjalnie włączone w prymat biskupa Rzymu. Rodzi to dalsze implikacje praktyczne: otóż papież Franciszek sprawuje posługę Piotrową w celu głoszenia Ewangelii z uwzględnieniem innych biskupów i całego ludu Bożego rozsianego po wszystkich diecezjach świata communio consensu - jak to ujmuje Sobór Watykański II - a więc „za obopólną zgodą”25. Szczególna pozycja biskupa Rzymu wobec innych biskupów i pozostałej reszty ludu Bożego urzeczywistnia się w radykalności jego posługi. Ostatecznie zaprojektowana przez papieża Franciszka śmiała i zdecydowana reforma Kurii rzymskiej uznana być musi za eklezjalny „znak czasu”. Zarówno ten znak czasu, jak i wiele innych, rzeczywiście staną się - w teologicznym sensie - godnymi tego miana, jeśli ich realizacja dokona się

\footnotetext{
${ }^{24}$ OR(D) 45 (2015), nr 8 z 20 II 2015, 3.

25 Sformułowanie pochodzi z DE, nr 14, gdzie znalazło zastosowanie ze względu na wspólną drogę Kościoła Rzymu z później dopiero odłączonymi Kościołami wschodnimi. Tłumaczenie wyrażenia, które przedłożyli K. Rahner, H. Vorgrimler, Kleines Konzilskompendium, Freiburg i. Br. $2008^{35}$, s. 242, okazało się niezbyt jasne: rozumienie owego: „za powszechną zgodą” Stolicy Świętej wydaje się być w tym tłumaczeniu tekstów soborowych raczej słabe. Nowe tłumaczenie: Die Dokumente des Zweiten Vatikanischen Konzils. Konstitutionen, Dekrete, Erklärungen, Lat.-dt. Studienausgabe, hg. v. P. Hünermann, Freiburg i. Br. 20062 (HThKVatII, 1), s. 230, właściwie oddaje: „communi consensu“ przez: „za obopólną zgodą“. Tekst soborowy mówi: Stolica Święta „za obopólną zgodą“ miarkowała (strony), gdy powstawały różnice poglądów odnośnie wiary czy dyscypliny między złączonymi Kościołami Wschodu i Zachodu.
} 
„W świetle Ewangelii”26. Pracę w tym kierunku zainicjował właśnie biskup Rzymu. Przeprowadzenie reformy Kurii jest znakiem prymatu papieża Franciszka na drodze, po której podąża Kościół.

\section{Biskup Rzymu a biskup Kościoła lokalnego}

Między Głową kolegium biskupów, papieżem, a każdym poszczególnym biskupem istnieją wzajemne sakramentalno-jurydyczne stosunki. W służbie ludu Bożego papież Franciszek ma własną miarę tych stosunków. Wybiera najbardziej rozległy horyzont ludu, aby następnie określić służbę biskupią: „Zadaniem papieża jest (...) zagwarantować jedność Kościoła. Jest to zadanie, które ma przypominać, że pierwszym obowiązkiem pasterzy jest karmić owce (...), które powierzył im Pan oraz po ojcowsku szukać, z miłosierdziem i bez fałszywego strachu, zaginionych owiec (...): poszukiwać tych, które odeszły”. A w odniesieniu do ludu jako całości dodaje: „Zadaniem papieża jest przypominanie wszystkim, że autorytet w Kościele jest służbą. (...) Papież jest (...) 'najwyższym sługą', servus servorum Dei, gwarantem bezpieczeństwa i zgodności Kościoła z wolą Boga, z Ewangelią Chrystusa i z Tradycją Kościoła. Musi on zrezygnować z własnej samowoli, gdy równocześnie - z woli samego Chrystusa - 'jest najwyższym pasterzem i nauczycielem wiernych' (kan. 749) i 'w Kościele sprawuje najwyższą, pełną, bezpośrednią i powszechną władzę zwyczajną' (por. kan. 331)"27. Stanowi to wyraźną wypowiedź dogmatyczną co do rozumienia przez Franciszka prymatu biskupa Rzymu w perspektywie zarządzanej przez biskupów communio Ecclesiarum; stanowi wypowiedź opartą o zasadę sub Petro. Biskup rzymski jest pierwszym duszpasterzem ludu Bożego ${ }^{28}$, a tym samym pierwszym duszpasterzem biskupów. Na mocy swojego urzędu jest równocześnie gwarantem jedności i wspólnoty w Kościele. To on w Kościele animuje sposób rozumienia idei sprawiedliwości i miłosierdzia. Wielkość biskupa Rzymu tkwi w jego „służebnej służbie”.

\footnotetext{
26 Por. KDK 4: „znaki czasu” wymagają wyjaśnienia „w świetle Ewangelii”.

27 Przemówienie papieża Franciszka (przyp. 15), s. 180-182.

28 Por. DB, nr 2.
} 
Zalecenia, które biskup Rzymu kieruje do biskupów w odniesieniu do ich diecezji, sam urzeczywistnia w odniesieniu do całego świata: pragnie zapewnić wszelką różnorodność, która byłaby odzwierciedleniem miłości Chrystusa do wspólnoty, do jedności. „W Kościele każde pierwszeństwo ma swój początek w miłości, musi być realizowane w miłości i miłość uznawać za swój cel”29. Przez pryzmat duchowego światła oświetlającego osobę ludzką papież Franciszek kontynuuje swoją myśl: „Także w tym Kościół rzymski ma odgrywać pierwszorzędną rolę: Jak w miłości posiada pierwszeństwo, tak każdy Kościół lokalny jest powołany do pierwszeństwa w miłości”. Sprawowanie urzędu biskupa sprowadza zatem do przewodniczenia w miłości; święcenia biskupie pozostają w służbie miłości.

Należy stwierdzić: służba biskupa w swej sakramentalnej istocie jest odwzorowaniem tej miłości, jaką ma Chrystus do Kościoła. Służba ta jest zatem zrównana w gruncie rzeczy z małżeństwem (por. Ef 5,32). Biskup Rzymu urzeczywistnia swój obraz i przedstawicielst wo wobec całego Kościoła na ziemi. Jest to szczególny sposób służby biskupiej. Ponieważ tego rodzaju odpowiedzialność przysługuje tylko biskupowi Rzymu, stanowi integralny składnik prymatu oraz służby Piotra w Kościele. Ewangeliczna interpretacja, sakramentalno-hierarchiczna natura władzy w Kościele oraz koordynowanie zadań nad całym Kościołem są dalszymi elementami, właściwymi biskupowi Rzymu jako podmiotowi prymatu Piotra. Kolegialny sposób sprawowania prymatu przez papieża Franciszka jest miarą koniecznej „wspólnoty hierarchicznej”30, co wzajemnemu słuchaniu, wspólnym poszukiwaniom i odkryciom zapewnia właściwą przestrzeń. Współczesne społeczeństwo zachodnie określa to mianem „płaskiej hierarchii” co jednak nie powinno być utożsamiane ze słabą hierarchią.

\section{Papież a zmysł wiary całego ludu Bożego}

Lud Boży w całej swej różnorodności na mocy chrztu jest podmiotem troski o pomyślność - doczesną i wieczną, co zresztą papieżowi

29 OR(D) 45 (2015) nr 8 z 20 II 2015, s. 7

$30 \mathrm{KDK}, \mathrm{nr} 22$. 
Franciszkowi mocno leży na sercu w odniesieniu do każdego człowieka. Biskup Rzymu musi być świadomy czego i w jaki sposób doznaje lud Boży. Tylko wtedy będzie „gwarantem dla wszystkich

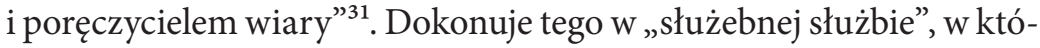
rej widzieć należy teologiczny habitus jego osoby.

Prerogatywa biskupa Rzymu, by służyć wszystkim, odnosi się także do innych biskupów, jednak należałoby ją ujmować jeszcze bardziej uniwersalnie.

Swe rozumienie związku biskupa i ludu Bożego, wyrażonego też związkiem każdego biskupa do swojej diecezji, papież Franciszek wyjaśnia w adhortacji apostolskiej Evangelii gaudium: „Biskup zawsze powinien budzić komunię misyjną w swoim Kościele diecezjalnym, dążąc do ideału pierwszych wspólnot chrześcijańskich, gdzie wierzących ożywiały jedno serce i jeden duch (por. Dz 4,32). Dlatego niekiedy stanie z przodu, aby wskazać drogę i podtrzymać nadzieję ludu, innym razem zwyczajnie stanie pośród wszystkich ze swą prostą i miłosierną bliskością, a w pewnych okolicznościach powinien iść za ludem, aby pomóc tym, którzy zostali z tyłu, a przede wszystkim dlatego, że sama owczarnia ma swój węch, aby rozpoznać nowe drogi. W swojej misji krzewienia komunii dynamicznej, otwartej i misyjnej powinien pobudzać i starać się o dojrzałość form uczestnictwa, proponowanych w Kodeksie Prawa Kanonicznego oraz innych form dialogu duszpasterskiego, pragnąć słuchać wszystkich, a nie tylko niektórych, zawsze gotowych prawić mu komplementy" (EG 31).

Obecny biskup Rzymu swą służbę Piotra realizuje z dużą duszpasterską elastycznością. Jest ona reakcją na powszechną dziś nieprzewidywalność w świecie i w Kościele. Takiej samej elastyczności żąda się obecnie od biskupów. Papież Franciszek w swej biskupiej służbie dla miasta Rzymu i całego kręgu ziemi mocno zabiega o doczesne dobro oraz zbawienie wieczne całego ludu Bożego, raczej pośrednio odwołując się przy tym do teologicznej „słuszności”, która przecież nie może tracić $\mathrm{z}$ oczu wszelkich niedostatków, nędzarzy, lekceważonych czy wreszcie nadzwyczajnych wydarzeń. W obrazowy sposób

31 Papież Franciszek w słowie powitalnym z okazji otwarcia (przyp. 15), 82. 
przedstawia to idea pasterza. Ciągłe akcentowanie przez Franciszka konieczności podążania cum Petro nierozdzielnie łączy się z sub Petro.

Widzące oczy papieża Franciszka z wdzięcznością dostrzegają obecność różnych charyzmatów w ludzie Bożym. Wszystkie charyzmaty wiary należy oceniać pod kątem ich przydatności dla $K_{\text {Kościoła }}{ }^{32}$. Odnosząc się do synodalnej drogi Kościoła oraz do charyzmatów wśród zgromadzonych na Synodzie Biskupów 2014, papież Franciszek konkluduje: „A kiedy Kościól, w różnych swoich charyzmatach wyraża się w komunii, nie może się mylić: to jest piękno i moc sensus fidei, tego nadprzyrodzonego zmysłu wiary, który jest dany przez Ducha Świętego, abyśmy razem mogli wszyscy wejść w istotę Ewangelii i nauczyć się naśladować Jezusa w naszym życiu. Nie powinno to być postrzegane jako motyw zamętu i trudności."33.

Oto przybyły z Ameryki Łacińskiej biskup Rzymu mówi o „zwyczajnej” pobożności ludu Bożego. Ewangelizacyjna siła pobożności ludowej jest zdaniem papieża Franciszka stymulatorem sensus fidei. Taka duchowość „nie jest pozbawiona treści, lecz ją odkrywa i wyraża bardziej za pośrednictwem symboli niż rozumu praktycznego, a w akcie wiary podkreśla bardziej credere in Deum niż credere Deum" (EG 124). Odnośnie dogmatu i duszpasterstwa papież Franciszek w równym stopniu podejmuje teologiczne co i praktyczne zastosowanie pobożności ludowej. Grupa uniwersyteckich dogmatyków nie wychodzi poza tę materię.

Podsumowując, można powiedzieć, że biskup Rzymu urzeczywistnia sprawowanie prymatu Piotra przez budzenie zmysłu wiary wszystkich; słucha wszystkich, a po dojrzałym rozróżnieniu Ducha, akceptuje. Papież daje gwarancję wzrostu i aggiornamento sensus fidei w ludzie jedynego Boga.

\section{Refleksje końcowe}

Na zakończenie tych wywodów niech posłuży myśl pochodząca z pracy Glaubensparadoxe (Paradoksy wiary) francuskiego jezuity

32 Por. KL 11: „świadomie, czynnie i owocnie”.

33 Przemówienie papieża Franciszka (przyp. 15), 180; KK, nr 12; por. nr 35; DK nr 9. 
i późniejszego kardynała Henri de Lubac (1896-1991): „Wszelkie formuły, wszelkie środki ostrożności, jakie można tylko zastosować w obronie ortodoksji czy wreszcie wszelkie skrupuły oraz wszelkie bariery mogą okazać się bezsilne, by zachować czystość wiary. Jeśli brakuje ducha, dogmat jest tylko mitem, zaś Kościół jest tylko partią"34. Teologiczny ogląd z wiarą i rozumnie ukazuje oczywistość nader kąśliwych słów de Lubac, gdy mówi on o Duchu, który w Kościele i teologii nie zajmuje miejsca ponad literą. Teologiczny ogląd z wiarą i rozumnie ukazuje oczywistość klarownych słów i odważnych czynów sprawującego władzę prymacjalną, papieża Franciszka, którego celem jest wyniesienie i waloryzacja całego ludu Bożego na jego drogach.

tłum. Rafał J. Kupiszewski

${ }^{34}$ H. de Lubac, Glaubensparadoxe, Freiburg i. Br. $2005^{2}$, s. 12. 